THE ORIGINS OF THE UNITED ARAB EMIRATES 
By the same author

Qatar: Past and Present (forthcoming) 


\section{THE ORIGINS OF THE UNITED ARAB EMIRATES}

A Political and Social History of the Trucial States

Rosemarie Said Zahlan

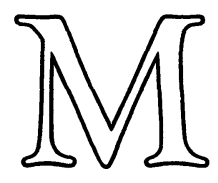


(C) Rosemarie Said Zahlan 1978

Softcover reprint of the hardcover 1st edition 1978

All rights reserved. No part of this publication may be reproduced or transmitted, in any form or by any means,

without permission

First published 1978 by

THE MACMILLAN PRESS LTD

London and Basingstoke

Associated companies in Delhi

Dublin Hong Kong Johannesburg Lagos

Melbourne New York Singapore Tokyo

British Library Cataloguing in Publication Data

Zahlan, Rosemarie Said

The origins of the United Arab Emirates.

I. United Arab Emirates-History 2. United Arab Emirates-Politics and government

I. Title

$$
953^{\prime} \cdot 5^{\prime} \text { o5 } \quad \text { DS }_{247} \text {.T88 }
$$

ISBN 978-1-349-03951-7 ISBN 978-1-349-03949-4 (eBook)

DOI 10.1007/978-1-349-03949-4

This book is sold subject

to the standard conditions

of the Net Book Agreement 
To Tony 


\section{Contents}

List of Illustrations $\quad$ ix

Acknowledgements $\quad \mathrm{x}$

Introduction $\quad \mathrm{xi}$

Note on Transliteration $\quad$ xix

Map $\quad \mathrm{xx}-\mathrm{xxi}$

I The Trucial States in 1919: Rule by Tradition I

Abu Dhabi $\quad 8$

Dubai $\quad$ I I

Sharjah $\quad$ I3

Ajman and Umm al-Qaiwain 15

2 The Aftermath of War: Perpetuation of Control I 7

Reconsideration of Policy 17

Reorganisation of Administration 22

Treaties with Arab Rulers $\quad 25$

The Officers of Government: Title and Function 27

The Political Resident in Bushire $\quad 27$

The Residency Agent in Sharjah $\quad 28$

The Political Agent in Bahrain 30

The Medical Officer on the Trucial Coast $3^{1}$

The Political Agent in Muscat 32

The Senior Naval Officer, Persian Gulf Division $\quad 32$

3 The Challenge to Power: Brother, Nephew and Son 34

4 Maintenance of Power: Political and Social Fabric 55 The Ruler's Economic Base $\quad 5^{6}$

Administrative Functions $\quad 57$

Maintenance of the Ruler's Authority $\quad 5^{8}$ 
Relations with Britain

The Consequences of the Decline of a Ruler's Authority

5 Saudi Arabia and Iran: Outside Pressures

The Back Door: Wahhabi Influence in 1925

The Sea Front: Iran in 1928

6 Establishment of the Air-Route: Test of Imperial Policy

7 The Preliminary Oil Concessions: Triumphant

Implementation of 1922 Agreements: Ultimatum of I937

Capitulation of Abu Dhabi

8 Territorial Claims: Saudi Arabia and Iran

9 Boundary Disputes: Chaos in Order

Io The Reform Movement of Dubai: The Beginnings of Democracy

I I The Exercise of Power: British Representatives

K. B. 'Isa bin 'Abd al-Latif OBE, Residency Agent I919-35

Lieutenant-Colonel Sir T. C. W. Fowle KCIE, CBE, Political Resident 1932-9

I2 The Trucial States in 1939: The Dawn of a New Age I80

I3 Epilogue: The Emergence of the United Arab Emirates I90

Notes

Appendix I: Genealogy of the Ruling Families of the

Trucial States 


\section{List of Illustrations}

I Shaykh Shakhbut of Abu Dhabi, who succeeded to the Rulership in 1928

(Paul Popper Ltd)

2 Lt.-Col. Sir Trenchard Fowle, KCIE, CBE, Political Resident in the Persian Gulf, I932-9

(Courtesy Mrs D. Hall)

3 Ras al Khaimah

(G. M. Lees; Courtesy of the Royal Geographical Society)

4 The Fort at Fujairah

(Lt.-Col. Sir R. Hay; Courtesy of the Royal Geographical Society)

5 The peace agreement between Sultan bin Saqr and Khalid bin Ahmad of Sharjah i924 (see p. 48)

(Courtesy of the India Office Records R/I5/I/276)

6 Petition from rulers and notables concerning 'Abd al-Rahman of Hirah (see p. 63)

(Courtesy of the India Office Records R/I5/I/279)

7 A humorous approach to the difficult task of delineating boundaries in desert areas. (Initialled by J. G. L., probably J. G. Laithwaite, Principal at the India Office, 1935, during the Anglo-Saudi negotiations)

(From the Public Record Office, Fo371/189o6, E2724, 30 April I935)

8 Dubai

(Lt.-Col. Sir R. Hay; Courtesy of the Royal Geographical Society)

9 Frank Holmes

io The Creek at Dubai

(Lt.-Col. Sir R. Hay; Courtesy of the Royal Geographical Society)

I I The Ruler of Umm al-Qaiwain

(Lt.-Col. Sir R. Hay; Courtesy of the Royal Geographical Society)

12 The Fort of the Shaykh of Abu Dhabi

(H. Burchardt; Courtesy of the Royal Geographical Society)

I 3 The Ruler of Ajman and his camel

(Lt.-Col. Sir R. Hay; Courtesy of the Royal Geographical Society)

14 Shaykh Shakhbut of Abu Dhabi coming off to call upon the

Political Resident

(Lt.-Col. Sir R. Hay; Courtesy of the Royal Geographical Society)

15 Triad 1916

(Crown Copyright; Courtesy of The Ministry of Defence)

I6 Crocus September I942

(Crown Copyright ; Courtesy of The Ministry of Defence)

17 Fowey June $194^{2}$

(Crown Copyright; Courtesy of The Ministry of Defence) 


\section{Acknowledgements}

Unpublished Crown Copyright material in the India Office Library and Records, and in the Public Record Office transcribed here appear by permission of the Controller of Her Majesty's Stationery Office. My article, 'The Preliminary Oil Concessions in Trucial Oman, 1922-1939', that appeared in International Interactions, vol. 3, no. 2, 1977, is based on Chapter 7 of this book.

While it would be impossible to thank everyone who helped me in the preparation of this study, I would like to single out a few persons to whom I am particularly grateful. The staff of the India Office Library and Records, especially Martin Moir and Penelope Tuson, have provided me with generous assistance in my efforts to locate and understand the wide variety of records available on the Gulf. I also wish to thank Lady Honor Fowle for providing me with an apt description of her life in Bushire when her late husband was Political Resident. Khaldun S. Husry, Joseph J. Malone and George Rentz have read and made useful comments on the manuscript. I owe much to my family, my mother and brother, Edward W. Said, in particular, for all their help. Above all, however, I wish to thank my husband, A. B. Zahlan, to whom this book is dedicated: his valuable insights, together with his patience and encouragement, greatly facilitated the completion of this book.

It goes without saying that I alone am responsible for all errors and shortcomings. 


\section{Introduction}

The creation of the United Arab Emirates in December 1971 ended a century and a half of the existence of the Trucial States in special treaty relations with Britain. When they first signed the General Treaty of Peace in I820, the tribal chiefs in the southern part of the Arabian Gulf could hardly have been described as rulers even in the loosest sense of the word, for their respective positions were governed by the vicissitudes of tribal loyalties, which caused an amorphous and fluctuating political structure. As time went by, and the same chiefs, and later their descendants, were drawn into further treaties with Britain, they began to acquire a certain amount of stability and authority as rulers: the responsibility of each new ruler for fulfilling his treaty obligations towards Britain made for continuity and a gradual stratification of certain political and social elements in the land he controlled, so adding a new dimension to his sovereignty. The tribal chiefs gradually evolved into rulers and the areas over which they exercised a certain amount of jurisdiction into shaykhdoms. Although both elements were upheld by commitments to Britain, it would be wrong to disregard the British role in the development of the tiny states, and it would be equally wrong to maintain that the only relevance of these states was in their relation to the power that dominated them for I5I years.

The treaty of 1820 was imposed on the chiefs by the British government of Bombay, which wanted to keep the Gulf route to India safe and open. Although the most important clause of the agreement was the cessation of plundering and piracy on land and sea, other terms, such as the commitment to desist from the 
slave trade, were to become central to the internal and external evolution of the states. The 1820 agreement protected British vessels from attack but it did not prevent warfare at sea between the tribes of the coast; so in I835 the chiefs of Abu Dhabi, Dubai, Sharjah and Ajman signed a one-year truce in which they undertook to report any aggression to the British authorities rather than take it upon themselves to retaliate. The truce was renewed the next year and at various intervals until I 853, when the Perpetual Maritime Truce was signed and the chiefs undertook to call a complete halt to all hostilities at sea. Other treaties with Britain included the undertaking by the chiefs to stop the importation of slaves into their respective territories (never actually committing themselves to the total suppression of the slave trade), and the I902 agreement whereby they promised to prohibit the importation and exportation of arms for sale in their lands. The climax was reached in 1892, when the Exclusive Agreement was signed; in it, the rulers, for by now their relations with Britain had added an impressive dimension of stability to their respective positions, undertook not to enter into any agreement or correspondence with any power other than Britain, and not to cede, sell or mortgage any part of their territory. Although the binding influence of the treaties with Britain consolidated the positions of the chiefs, the clauses of the treaties reflected Britain's overwhelming concern for the safety of the route to India. The treaties affected the social and economic conditions of the area that were of concern to British interests - the curbing of Qasimi sea power, the slave trade, the arms trade, and the cessation of all foreign relations and communications-but did not attempt to intervene in tribal relationships. One feature of these relationships was the rivalry between the Hinawi and Ghafiri factions into which the entire area, from the Trucial Coast to the inner reaches of Oman, was divided. This factionalism was exacerbated in the early eighteenth century when a civil war broke out between tribal chiefs and 'ulema' (religious leaders) over the disputed succession to the imamate of Oman. The war soon engulfed the whole of Oman, including the Trucial Coast, dividing it into the two factions, those who followed the Bani Hina and those who followed the Bani Ghafir. The alignment of the tribes into Hinawi and Ghafiri factions continued long after the war was over, and survived well into the twentieth century.

On the Trucial Coast, the opposition between the Ghafiriyyah and the Hinawiyyah was manifested in the enmity that existed between the two main tribes, the Bani Yas and Qawasim (plural of Qasimi). The nineteenth century was chequered with the immense struggles between them, the Bani Yas being Hinawi, the Qawasim Ghafiri. The Qawasim, with headquarters in Sharjah and Ras al- 
Khaimah as well as an outlet on the Gulf of Oman in the Shimayliyyah, were basically a seafaring people who achieved fame as able sailors and notoriety as pirates; indeed it was they who were responsible for the appellation 'Pirate Coast' for the Trucial Coast. As the potency of the Qawasim became curtailed by the successive treaties with Britain that bound them to refrain from any form of sea warfare, that of the Bani Yas, a land power, began to grow correspondingly. It reached its peak during the rule of Zayid bin Khalifah (1855-1909) of Abu Dhabi. He consolidated the power of the Bani Yas and extended his influence and authority over the neighbouring tribes of the Manasir, the $\mathrm{Na}$ 'im and the Dawahir (plural of Dahiri), thus becoming a potent force in the Dafrah and Buraimi areas, well beyond the confines of Abu Dhabi town. By the turn of the century, Zayid had achieved for Abu Dhabi a position of unquestioned importance on the Trucial Coast; it could command respect not only in the coastal regions but in the hinterland as well. Almost concurrently with the rise of Abu Dhabi, another Bani Yas shaykhdom, Dubai, began to challenge the importance of Sharjah as a seafaring centre; the growth of Dubai as the major entrepot of the Trucial Coast led to its development as the focal point of the trade in the region, the position held by Sharjah being supplanted once again.

The ascendancy of the Bani Yas in the twentieth century can thus be regarded both as a result of the treaty relations with Britain that curbed the sea power of the Qawasim, their main rivals, and as the natural outcome of the evolution of Abu Dhabi and Dubai, coupled with the decline of Sharjah and Ras al-Khaimah. On the one hand, therefore, Britain maintained a loose form of protectorate over the shaykhdoms, and this provided for their stratification as such; on the other, their own development was relatively unhampered by the confines of overlordship, for British policy was officially against interference in internal affairs. The local history of the shaykhdoms developed at most times as an independent process, for they were governed in the traditional style of bedouin society, the ruler having absolute power and governing in a manner that had to be accepted as fair to all. No administrative policies or constitutions were superimposed by Britain. No attempt was made by the British authorities to introduce even the slightest change in the existing political framework. In fact, until the twentieth century, the only outward signs of the Raj were official visits by British naval and political authorities, and the special privileges accorded to the Indian traders resident in the area.

The purpose of this study is to examine, for the seven shaykhdoms known as the Trucial States, their internal development during a vital and neglected period of their history. The local history 
of the Arabs of the Trucial Coast has always been seen as an almost extraneous detail in the development of the Gulf as a major arena of conflict between the great powers before World War I, and later as an important strategic and economic focal point for Britain. With the emergence of the United Arab Emirates in 1971, a spate of literature on the member states of the new federation suddenly appeared, in numerous languages; articles and books discussed the area from every conceivable point of view--economic, political, financial, technological, agricultural, social, and so on-for the relatively brusque birth of the $\mathrm{UAE}$, eager to take its place amongst the sovereign independent nations of the world, was accompanied by an awareness of its long isolation and a desire to end it. One factor is common to all the varied works on the UAE: a silence on anything pertaining to the internal history of the former Trucial States, apart from a few anecdotal episodes. This is especially true for the period following the detailed historical narrative drawn up in J. G. Lorimer, Gazetteer of the Persian Gulf, Oman and Central Arabia (Calcutta, I908-1915). The Gazetteer, which is still the greatest reference work on the Gulf and Oman, was compiled in 1908 by an officer of the Indian Political Service, and has only recently been generally available. It provides a vast amount of knowledge on the internal history of the Gulf states, particularly during the nineteenth century, but its narrative concludes just before the outbreak of World War I. A vacuum did not exist from that time to the present, although the existing literature on the development of the Trucial States would lead one to believe so. This work attempts to bridge part of the gap.

In the aftermath of World War I, as the old order in Europe and Asia collapsed, the Trucial States at first seemed untouched by the turbulence of outside events. Their people continued in their occupations and preoccupations at the same unhurried pace as before, and seemed likely to do so for a long time to come. But, despite their remoteness, the shaykhdoms were drawn, almost reluctantly, into the foreground of events during the early years of the twentieth century, for the creation of Saudi Arabia and the rise of nationalism in Iran directly affected the relations of the shaykhdoms with each other and with their neighbours. Furthermore, the area could not escape the ramifications of the new technological age. While 'Abd al-'Aziz ibn 'Abd al-Rahman Al-Sa'ud (usually referred to as Ibn Sa'ud) and Riza Shah were asserting themselves as the new forces in the Gulf, the Trucial Coast became involved in the development of the British air-route to India for civil and military aircraft. It was because of the air-route that a new shaykhdom, Kalba, was created in 1936 ; and it remained in existence until 1952, when it disappeared almost as suddenly 
as it had come into being. Also, and here the repercussions are only too obvious today, the Arabian peninsula began to be marked as a great potential oilfield, thus making the shaykhdoms es: ecially vulnerable to the machinations of governments and big business.

In this book, the first contact of the Trucial Coast with these new forces is examined in detail, together with the parallel internal evolution of each shaykhdom. The latter has been disregarded all too often, in the face of the vast incongruity of the implications of British imperial history and the limitations of local Arab history. Another reason has undoubtedly been the paucity of local Arab historical materials, which appear particularly few and barren when compared with the remarkably detailed annals that have been preserved in Britain and India, through the smoothly operating machinery of officialdom. This study has taken advantage of the new regulations regarding access to the official records of British administrators in the Gulf, which are kept on file in London. Of these, the most valuable for present purposes are the recently declassified Persian Gulf Territories Residency Records in the India Office Records. In the absence of Arab records, they provide the best source material for any aspect of the local history of the Arab shores of the Gulf. They include the Bushire Residency Records, and the Bahrain, Muscat, Kuwait and Sharjah Agency Records, all of which contain a wealth of information on local events-events that were often considered irrelevant to imperial considerations and so not notified to London or Delhi. Many of these records are in Arabic. ${ }^{1}$ They include reports on day-to-day events compiled by the Residency Agent (an Arab stationed at Sharjah, until I939 the only British representative on the Coast), whose intimate knowledge of the area and its people, assiduously cultivated and maintained, was owing not only to his official position, but also to his wide financial interests in the shaykhdoms themselves; correspondence addressed to the Political Residents and Agents by the rulers and leading men of the shaykhdoms, and copies of the answers; petitions to the British authorities about outstanding debts and the manumission of slaves; and regular series of reports, compiled in the form of intelligence summaries and diaries, on all movements, tribal and otherwise, within the coastal and inland regions of the shaykhdoms.

No comprehensive conclusion on the history of the area can be reached without a detailed knowledge of the internal and external factors that shaped its affairs. The interaction and synthesis of these factors are particularly relevant to the first half of the twentieth century, for it was this period that provided the vital link between the nineteenth century, when the Raj was at its zenith, and the middle of the twentieth century, when the British government of 
India was dissolved, the first and most conclusive feature of the dismemberment of the British Empire. It was this period also that lay the foundations for the modern development and transformation of the Gulf. It is therefore important to examine the internal and external features of the shaykhdoms of the Trucial Coast in the light of contemporary Anglo-Arab relations during the inter-war period, the period referred to by one writer as 'The Years of Good Management'.2

And yet, in spite of these vicissitudes [basically, the turbulence in 1929 in Palestine], Britain remained paramount in the Middle East, unchallenged by any power of equal magnitude, and able to maintain order thanks to its serenity, and aura of empire, and its ability to summon reinforcements from Malta or India in case of need. British paramountcy endured until the end of the Second World War, and for longer in Middle Eastern imaginations; the shadow of power is long, and remains after the substance has gone. ${ }^{3}$

The 'substance' in the Arab countries was totally different in form and texture from that in the Gulf region as a whole. In Egypt, where British interest had been kindled by the 'overland route' to India, a project that culminated in the building of the Suez Canal, Britain had reigned supreme since the occupation of 1882 . Yet nationalist movements and popular uprisings did much to curb its influence, and the Anglo-Egyptian Treaty of ${ }_{193} 6$ officially terminated the British occupation. Although Britain still controlled Egypt, and this is best illustrated by the forcible intervention by the British ambassador in $194^{2}$ that resulted in Mustafa Nahas becoming the Prime Minister, the parliamentary monarchy had a fair amount of self-determination. In Iraq, where the British presence was established when British forces captured Baghdad from the Ottomans in 1917 and then proceeded to set up an internal government administration, the Hashimi Amir Faysal ibn Husayn became king in 1921. The next year an Anglo-Iraqi Treaty was drawn up (ratified in 1924) that gave Britain the instrument by which to exercise the mandate in Iraq; this was followed in 1930 by another treaty, which gave Iraq considerably more independence, allowing it to become a member of the League of Nations in 1932. As in the case of Egypt, the British presence continued to be a potent force, and in I94I the British again took control there, because of the pro-German sympathies of the Rashid Ali Gaylani movement. Transjordan was an emirate created in I92 I and allotted to the Hashimi Amir 'Abdallah ibn Husayn by Britain. In 1923, 1928 and 1934, successive treaties gave Transjordan a 
greater measure of independence, but it was not until 1946 that it became an independent kingdom. Palestine was administered as a British mandate, and never allowed to achieve even a minimal degree of self-determination, because of the promises made in 1917 by Balfour regarding the establishment of a national home for the Jewish people; the Palestinians, although deprived of their civil rights, reacted violently to the British administration, the best examples of this being the outbreaks of civil disturbance in 1922, 1929 and 1936 .

With the well-known exception of Palestine, all these states gradually achieved, in varying degrees and with varied success, the semblance of independence. With the advice and help of the British authorities, government administrations were set up, to see to the establishment and operation of the requisite machinery of modern states; a national press was formed; armies were built; and passports were issued. Relationships with other Arab countries began to develop, culminating in the formation of the Arab League in 1945 .

The Gulf states lived in a world apart. The binding clauses of the 1892 agreements meant that the shaykhdoms lived in almost complete isolation. As time passed, they became more introverted and effectively more remote, having little interest in the events of the outside world. The British authorities guarded the area with a jealous eye, and during the inter-war period no foreigner was granted a visa to visit the Coast; the isolation of the area can best be seen from the striking dearth, in the mass media, of news items on the Gulf (with the exception of Bahrain, and this only because of the intricacies of British policy in the islands). According to an India Office memorandum, British policy in the Gulf had been to

discourage any attempt by other Powers to compete with ourselves for their [the local rulers'] favours. The motive has not been a selfish one but is based on the knowledge gained from long experience that in dealing with Eastern Rulers it is essential to avoid placing in their hands the opportunity to play off one country against another. ${ }^{4}$

Bahrain and Kuwait were relatively less restricted than their southern neighbours, and it might be noted here that Woodrow Wilson's famous reference to the doctrine of self-determination had filtered through to the ruling family of Bahrain, although Political Agents there were not wont to take it seriously.

The long isolation of the Coast has been lifted completely today. 
The United Arab Emirates, greatly helped by the income derived from oil, has shown its determination to adapt as quickly as possible to contemporary conditions. Desalination plants have brought water into areas that have been parched since time immemorial; vast agricultural projects have resulted in the export, albeit on a small scale and only as an experiment, of fruit and vegetables; four-lane highways have opened up hitherto intractable desert areas; modern luxury hotels dot the coast and inland regions, in glaring contrast to the old barasti huts; a new satellite earth station gives all the territories of the UAE a link with the international satellite system; the largest dry-dock of its kind in the world is being built in Dubai; jumbo jets roar in and out of UAE airports at regular intervals; the UAE's businessmen play an important role in international markets; its leading statesmen are listened to with respect; and, finally, a modern defence system is being formed that will serve to strengthen the political unity of the states of the federation by the establishment of a common defence force.

Even with the most sophisticated infrastructure, however, it is impossible completely to shake off the centuries in just a few years. Occasionally there occurs an incident in which the essential characteristics of the land and its people, as determined by geography and long historical experience, break through the surface modernity and stand fully revealed. One such incident deserves mention. In August 1973, the son of the ruler of Dubai, Muhammad bin Rashid, also the Minister of Defence of the UAE, became involved in an armed clash over a timeless Gulf issue: rights to a water well. The well in question, on the ill-defined border between Sharjah and Dubai, had been dug by Dubai, and, when the inhabitants of Sharjah drew water from it, despite warnings to desist, Muhammad bin Rashid shot at them from a helicopter; undaunted, the people of Sharjah returned fire, and the helicopter was brought down. ${ }^{5}$

In this way the old pattern of life showed through again. Despite desalination plants and despite a written constitution that strongly emphasises the unity of the member states of the UAE, the old rivalry between Sharjah and Dubai erupted into violence. Instead of old and rusty rifles, a helicopter and modern machine-guns were used; otherwise, the incident could well have taken place in 1933 , I 893 or even 1853 . It is when time seems to stand still, as in this case, that we can see the past most clearly in perspective. 


\section{NOTE ON TRANSLITERATION}

The transliteration of Arabic words in this study originally followed the system adopted in the second edition of the ENCYCLOPAEDIA OF ISLAM (except in the case of place names that have a generally accepted form in English), with the following alterations:

$$
\begin{aligned}
& \overrightarrow{~ i s ~ t r a n s l i t e r a t e d ~ t h u s: ~} j \\
& \mathrm{G} \text { is transliterated thus: q } \\
& b \text { is transliterated thus: } z
\end{aligned}
$$

For the sake of simplicity, however, I have dropped the diacritical marks, apart from the 'ayn (') and the hamzah ('), in all but Appendix I and the bibliography. 


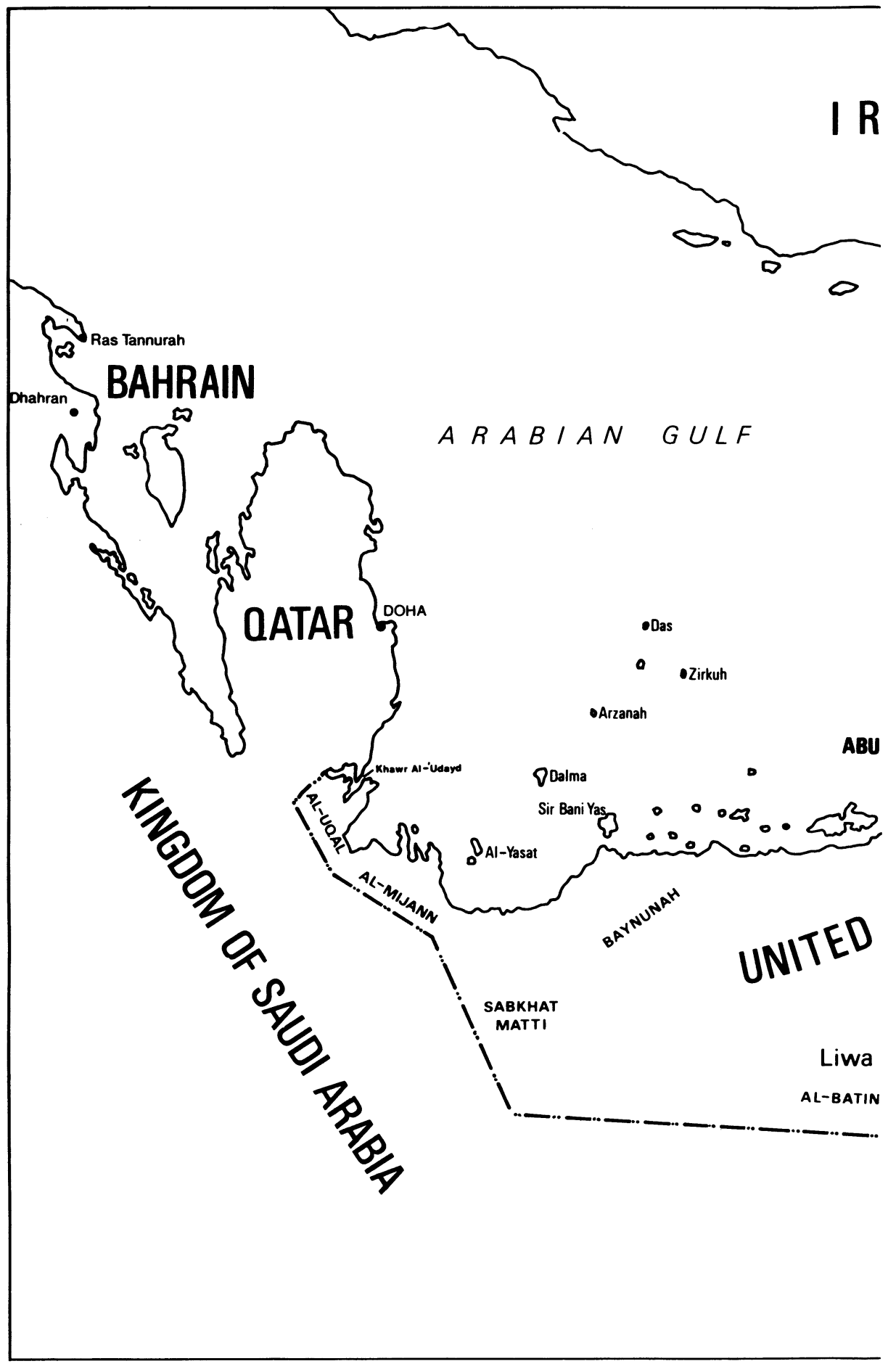




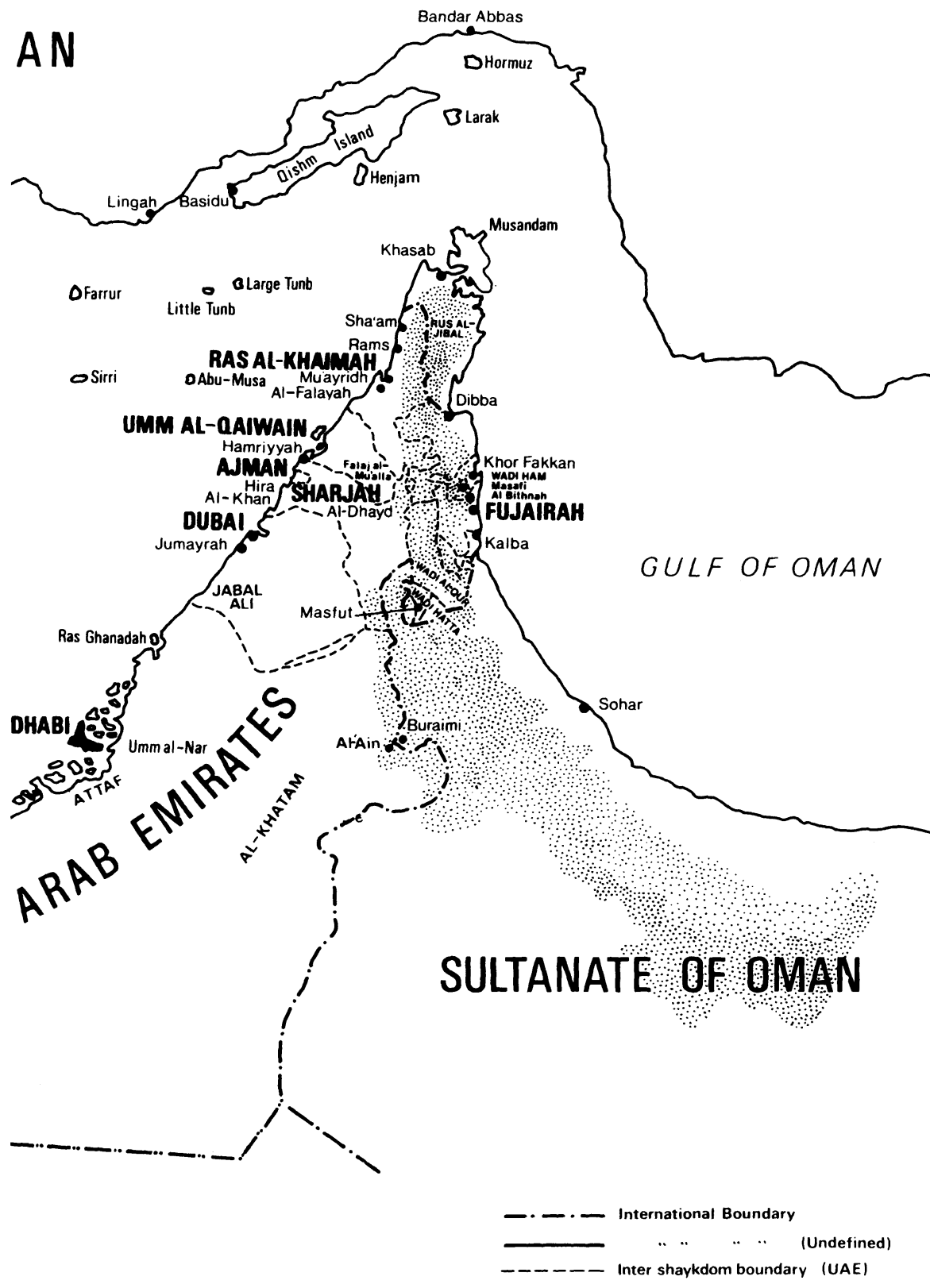

